e-ISSN: 2550-1313 | p-ISSN: 2087-9849

http://jurnal.fkip.unila.ac.id/index.php/jpp/

\title{
Evaluation of Students' Attitudes and Science Process Skills toward Middle School Science Subject in Indonesia
}

\author{
Margaret Dwi Wiwik Ernawati ${ }^{1}$, Asrial $^{2 *}$, Rahmat Perdana ${ }^{2}$, Sabila Eka Septi $^{2}$, Rahmi $^{2}$ \\ ${ }^{1}$ Department of Chemistry Education, Universitas Jambi, Indonesia \\ ${ }^{2}$ Department of Physics Education, Universitas Jambi, Indonesia \\ *Corresponding email: porigih@gmail.com
}

Received: 27 July 2021

Accepted: 27 August 2021

Published: 27 August 2021

Abstract: Evaluation of Students' Attitudes and Science Process Skills toward Middle School Science Subject in Indonesia. Objective: This research aims to determine the differences and the relationship between attitudes and science process skills in science learning in Batanghari Regency, namely Junior High School 34 Batanghari and Junior High School 35 Batanghari. Method: Quantitative method with associative and comparative type. The instrument in this study used a questionnaire for attitudes and an observation sheet for science process skills. Quantitative data analysis technique used random sampling with 140 students as respondents. Findings: Based on the t-test obtained sig.(2tailed) $0.048,0.047,0.039,0.038<0.05$, so there are differences in students' attitudes and science process skills. From the correlation test obtained sig. (2-tailed) of 0.035 and $0.037<0.05$ which indicated the relationship between attitudes and science process skills. Conclusion: Differences and the relationship between students' attitudes and science process skills in science learning at Junior High School 34 Batanghari and Junior High School 35 Batanghari.

Keywords: evaluation, attitude, science process skills.

Abstrak: Evaluasi Sikap dan Keterampilan Proses Sains Siswa terhadap Mata Pelajaran IPA Sekolah Mengah di Indonesia. Tujuan: Penelitian ini bertujuan untuk mengetahui perbedaan dan hubungan antara sikap dan keterampilan proses sains dalam pembelajaran IPA di Kabupaten Batanghari yaitu SMP 34 Batanghari dan SMP 35 Batanghari. Metode: Metode kuantitatif dengan tipe asosiatif dan komparatif. Instrumen dalam penelitian ini menggunakan angket untuk sikap dan lembar observasi untuk keterampilan proses sains. Teknik analisis data kuantitatif menggunakan random sampling dengan responden sebanyak 140 siswa. Temuan: Berdasarkan uji-t diperoleh sig.(2-tailed) 0,048, 0,047, 0,039, 0,038<0,05 yang mengindikasikan suatu antara hubungan sikap dan keterampilan proses sains siswa. Dari uji korelasi diperoleh sig. (2-tailed) sebesar 0,035 dan 0,037<0,05, ada hubungan antara sikap dengan keterampilan proses sains. Kesimpulan: Perbedaan dan hubungan sikap siswa dengan keterampilan proses sains pada pembelajaran IPA di SMP 34 Batanghari dan SMP 35 Batanghari.

Kata kunci: evaluasi, sikap, keterampilan proses sains.

\section{To cite this article:}

Ernawati, M, D, W., Asrial., Perdana, R., Septi, S, E., \& Rahmi. (2021). Evaluation of Students' Attitudes and Science Process Skills toward Middle School Science Subject in Indonesia. Jurnal Pendidikan Progresif, 11(2), 258-274. doi: 10.23960/jpp.v11.i2.202110. 


\section{INTRODUCTION}

Education is a skill that is passed down from one generation to the next with efforts to increase knowledge and training through teaching and learning efforts. Learning aims to help students develop critical and creative thinking skills (Wahyudi et al., 2017; Hong \& Talib, 2018; Crawley et al., 2019). 21 st Century Learning is one of the abilities that integrates literacy skills, knowledge skills, skills and attitudes, and mastery of technology (Anggraeni et al., 2019; Ramdani et al., 2019; Marshel \& Ratnawulan, 2020). The main priority for 21 st century learning and education is to produce intellectual generations and be able to combine knowledge and skills that are used as the basis for social life (Darmaji et al., 2019; Raharjo et al., 2019; Flores-Tena, 2020). Education is generally divided into stages such as preschool, elementary school, high school and then college, university or internship. Basic education also includes one of them is junior high school.

Basic education is the most basic level of formal education in Indonesia (Effendy \& Leilani, 2021; Emilzoli et al., 2021; Mutiani, 2021). Basic education also includes junior high school which aims to lay the foundation for intelligence, knowledge, and skills (Anisah \& Suntara, 2020; Kjeldsen, 2019; Zariæ et al., 2021). Middle School will be a solid and useful foundation when children will take education at a higher level. So the role of an educator is very important in this regard. In the first high school lessons, there are science subjects that discuss basic facts and concepts (Hutauruk, 2018; Anif et al., 2020; Century et al., 2020).

In a general sense, science is a representation of reality by scientists using scientifically justified methodologies and validity measures (Hidayat et al., 2019; Karaçam et al., 2020; Muslih, 2020). Understanding science or science as knowledge or as part of this knowledge seems to be the most basic understanding, so that the basic characteristics of what is called knowledge are inherent in science, even though science has special characteristics that are different from other types of knowledge. Science as the ability to understand concepts, principles of science, scientific activity, and scientific thinking is indispensable for students (Setiawan et al., 2017; Vosniadou, 2019; Cooper \& Berry, 2020).. Natural Sciences is a science that can be obtained with a scientific approach. Science at the SMP/MTs level is packaged in an integrated manner in science science which includes: physics, biology, chemistry, and earth and space sciences and science studies include aspects of products, processes, scientific attitudes and educational applications (Setia, 2016; Imaduddin \& Khafidin, 2018; Wulandari et al., 2019; Cooper \& Berry, 2020;).

Physics learning, which is mostly natural phenomena, is required to understand knowledge contextually. Physics is a branch of science that studies something concrete and can be proven mathematically closely related to human life and with physics all work becomes light because of the application of physics which is implied in sophisticated technology (Diah et al., 2018; Harefa, 2019; Nurmayani et al., 2018; Puspitasari et al., 2019). Physics is in fact one of the subjects that is considered heavy and is avoided by some students because it requires perseverance, seriousness and a lot of practice (Sultan, 2017; Rosdianto, 2017; Astalini et al., 2018) Students' understanding of a concept that begins with of the wrong concept will certainly be different from the scientific understanding possessed by experts or scientists in the field of physics (Warfa et al., 2018; Maison et al., 2019; Madu, 2020). Further more, this requires a scientific approach to science to improve and develop the knowledge experienced by students and the increase in students' conceptual knowledge can be seen through students' science process skills and attitudes. 
Attitude is a condition of mental emotional readiness to take a certain action when a situation is faced. One of the factors that influence the learning process is attitude. Attitudes are assessed based on several negative and positive aspects by looking at learning using observation sheets or journals (Erdogan, 2017; Rosdianto, 2017; Putra et al., 2018; Rosdianto 2018). Students' attitudes towards science significantly change their achievements in science. Enjoyment of learning in science (IPA) can be defined that every student who has a positive attitude towards science should have comfort and feel the pleasure and values of parents towards science subjects encourage parents to develop children's interest in a career in science (Maharaj-Sharma \& Sharma, 2017; Halim et al., 2018; Kurniawan et al., 2018). A positive attitude of students in accepting assignments is a good start for the student's learning process, on the other hand, if students are negative, they will tend to stay away, hate and avoid them (Setiawan, 2017; Ningsi, 2020; Sriyanti, 2021). It can be concluded that students' attitudes can show students' feelings towards the subjects being studied.

Science process skills are skills that are acquired through training in basic mental, physical, and social skills. Science process skills is included in the scientific method which is very important for students to improve students' process skills. Skills are very important for generating new knowledge through learning activities referring to behaviors that reveal their understanding of the world (Vansteensel et al., 2017; Stender et al., 2018; Vartiainen \& Kumpulainen, 2020). Students can develop scientific concepts by observing and mixing several theories so that they can become something new (Labouta et al., 2018; Solé et al., 2020; Stylinski et al., 2020). In this learning, students are required to experience for themselves, seek, try and draw conclusions from the process of the skills they perform (Kruit et al., 2018; Anna et al., 2019; Mutlu, 2020). So the process of science is very important for students to be realized in everyday life.

This research is in line with previous research conducted by (Sultan \& Bancong, 2017) on student attitudes towards science subjects and research conducted by (Utami \& Wutsqa, 2017) on science process skills. However, previous research did not compare students' attitudes and students' science process skills. In addition, previous studies did not perform some of the tests carried out in this study. The purpose of conducting a test of attitudes towards students' science process skills is to determine the relationship between students' attitudes and students' science process skills.

The urgency in this research is very important because there is no research that compares student attitudes with science process skills and some of the tests used are very useful to know about the comparison of attitudes and science process skills in each class and the comparison of indicators to be tested. According to (Sudibyo et al., 2018) attitude testing is a test to find out whether the test can confront students from practical problems. By looking at the importance of students' attitudes and science process skills from the questionnaire attachments and observation attachments, the researchers concluded the following objectives: (1) to compare the attitudes of students at Middle School 34 Batanghari and Middle School 35 Batanghari towards science subjects (2) to determine the comparison science process skills in students at Middle School 34 Batanghari and Middle School 35 Batanghari on science subjects (3) to determine the relationship between attitudes and science process skills in students towards science subjects.

\section{METHODS}

\section{Research design}

This study uses a quantitative method with a comparative type. Quantitative research 
is a field of inquiry that stands alone, is scientific in nature and aims to understand social reality (Manzilati, 2017; Rukin, 2019; Suwendra, 2018). The study also used a survey procedure. Survey research design is a quantitative research procedure in which the researcher administers a survey on a sample or on an entire population of people to describe attitudes, opinions, behaviors, or specific characteristics of the population (Creswell, 2012). The data obtained using numerical data with a Likers scale 5 . This study gains an understanding of a phenomenon from basic logic, usually including the perspective of the research population (Anggiato \& Setiawan, 2019; Hennink, 2020; Tolley, 2014). In essence, quantitative research observes people in the environment as well as in the social sciences.

\section{Research Instruments}

The instrument in this study used a questionnaire for the attitude variable and an observation sheet for the science process skills variable. The attitude questionnaire was adopted from (Astalini \& Kurniawan, 2019). There are 17 statement items from the two attitude questionnaire indicators, the first indicator is the Adoption of scientific attitude, there are 8 items and the second indicator is Fun in learning science, there are 8 statements. This instrument uses a Likert scale. A scale consisting of 5 points with a very good score of 5 , good is 4 , enough is 3 , not good is 2 , and very not good is 1 . Next is the observation sheet for the adoption process skills from (Darmaji et al., 2019). There are 9 statement items from two indicators of science process skills, namely classification, there are 5 statement items and the second indicator, namely Table Arrangement, there are 3 statement items. This instrument uses a Likert scale. A scale consisting of 4 points with a very good score is 4 , good is 3 , not good is 2 , and not good is 1 . The Grid of the student attitude questionnaire instrument used in this study are as follows:

Table 1. Grid of student attitude questionnaire instruments in science subjects

\begin{tabular}{clc}
\hline No. & \multicolumn{1}{c}{ Statements } & Indicator \\
\hline 1 & I like to read about things that don't match my previous & \\
thinking. & \\
2 & I don't like experiments if the results are the same. & \\
3 & Finding out about new things is not important. & Adoption of \\
4 & work in science lab is an interesting way to make a & \\
& living. & \\
5 & I like to listen to people whose opinions differ from & \\
& mine. & \\
6 & I feel bored hearing new thoughts & \\
7 & Talking to friends about science after school will be & \\
8 & boring & \\
\hline 9 & I want to teach science when I graduate from school & \\
10 & I don't like science lessons. \\
11 & Schools should have more science lessons every week. & \\
12 & Science lessons make me bored & Fun in learning \\
13 & Science is one of the most interesting school subjects. & science \\
14 & I want to do a science experiment at home. \\
15 & Science lessons are a waste of time. & \\
16 & I like going to places to study science. \\
17 & The material covered in science lessons is not & \\
\hline
\end{tabular}


The categories of student attitudes in grid of the science process skills questionnaire science subjects are shown in Table 2. The is presented in Table 3.

Table 2. Categories of Student Attitudes in Science Subjects

\begin{tabular}{ccc}
\hline Category & Adoption of scientific attitude & Fun in learning science \\
\hline Very not good & $8.0-14.4$ & $9.0-16.2$ \\
Not good & $14.5-20.8$ & $16.3-23.4$ \\
Enough & $20.9-27.2$ & $23.5-30.6$ \\
Good & $27.3-33.6$ & $30.7-37.8$ \\
Very good & $33.7-40.0$ & $37.9-45.0$ \\
\hline
\end{tabular}

Table 3. Item statements and indicators of science process skills in science subjects

\begin{tabular}{cll}
\hline NO. & \multicolumn{1}{c}{ Statements } & \multicolumn{1}{c}{ Indicator } \\
\hline 1 & $\begin{array}{l}\text { I like to read about things that don't match my previous } \\
\text { thinking. }\end{array}$ & \\
2 & I don't like experiments if the results are the same. & Classification \\
3 & Finding out about new things is not important. & \\
4 & work in science lab is an interesting way to make a living. & \\
5 & I like to listen to people whose opinions differ from mine. & \\
\hline 7 & Science lessons are fun. & Arrange Table \\
8 & I don't like science lessons. & \\
9 & Schools should have more science lessons every week. & \\
\hline
\end{tabular}

The intervals and categories of students' science process skills for science subjects are presented in Table 4. Regarding the science process skills of students, this research was carried out as many as 2 samples, namely class VII A and VII B samples with each class having 35 students. The sample consisted of two groups, namely the experimental group and the control group (Fromowitz, 2017).

\section{Population and Sample}

The population is the person who is the subject of research or the characteristics to be studied. The population of this study was 140 students consisting of 70 students from Middle School 34 Batanghari and 70 students from Middle School 35 Batanghari. The sampling technique is total sampling. The subjects taken were class VII A and VII B

Table 4. Categories of students' science process skills

\begin{tabular}{ccc}
\hline Category & Classification & Arrange Table \\
\hline Very not good & $5.0-5.75$ & $3.0-5.25$ \\
Not good & $8.85-12.5$ & $5.35-7.5$ \\
Good & $12.6-16.25$ & $7.6-9.75$ \\
Very good & $16.35-12.0$ & $9.85-12.1$ \\
\hline
\end{tabular}


which consisted of 40 women and 30 men. The sample in this study uses the Probability Sampling sampling technique, which is a sampling technique that provides equal opportunities for each member (element) of the population to be selected as a sample member (Achdiyat \& Utomo, 2018). The reason for using purposive sampling technique is because not all samples have criteria that match the phenomenon under study. Therefore, the authors chose a purposive sampling technique which stipulates certain considerations or criteria that must be met by the samples used in this study. The total number of samples that will be used in this study are students of class VII A and VII B of Middle School 34 Batanghari and Middle School 35 Batanghari.

\section{Data analysis technique}

The data analysis technique used was random sampling because the samples used were Middle School students in grades VII A and VII B who studied science according to the variables of attitude and science process skills. Using random sampling can reduce the potential for bias in the selection of cases to be included in the sample. Due to the homogeneity of the population, the sampling frame is clear and general in nature. The sampling technique was adopted because it estimates unbiased parameters and is better if the population is homogeneous (Alsabahi et al., 2021; Bankole \& Nasir, 2020; Tao \& Ning, 2018). From the data, data analysis was then carried out, namely data coding, data filtering and data analysis. In describing the data in the form of students' attitudes and science process skills, the statistics used are descriptive statistics and inverential statistics. Tests of description or presentation of large amounts of data which include the mean, mode, median, maximum, minimum, and standard deviation are descriptive statistics. Inverential in the form of independent sample $t$ test and correlation. Then test for normality, homogeneity, and linearity. Then the data were analyzed using SPSS 26 program to get the percentage, frequency, average and standard deviation. With this random sampling condition, data deviation is carried out.

\section{Research procedure}

In collecting data, the first activity that must be done is to select students based on the categories given by the researcher, then provide a questionnaire on student attitudes in science subjects. Then the questionnaire data was processed using the SPSS application. The use of the SPSS application functions to view descriptive statistics, in the form of mean, min, max, percentage, and category of students. The data needed in research can be collected or obtained from various data sources. The procedures for collecting data in this study are in accordance with the following diagram:
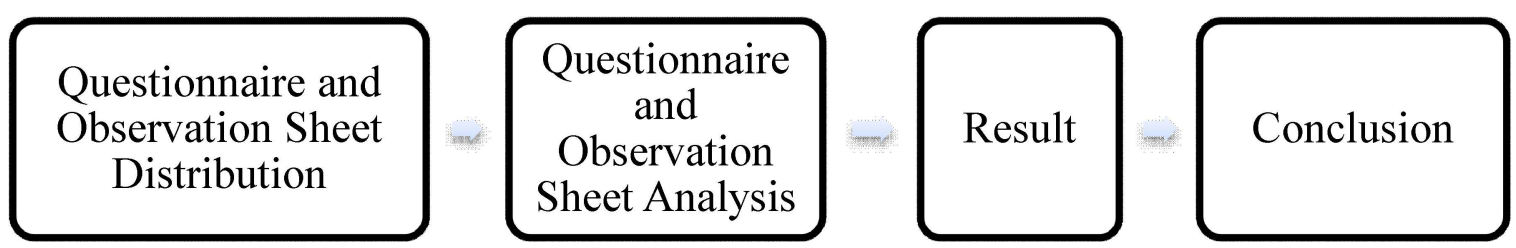

Figure 1. Research procedure 
RESULTS AND DISCUSSION Descriptive Analysis of Attitude and Science Process Skills

The following describes the results of descriptive statistics on students' attitude variables and students' science process skills in science subjects. With a question indicator on attitudes: attitudes towards science investigations, adoption of scientific attitudes. Question indicators on science process skills: Classification and Compiling Tables. Where the results obtained from the distribution of questionnaires to Middle School 34 Batanghari and Middle School 35 Batanghari to both classes, namely class VII A and VII B. The description of students' attitudes towards science on the indicator of the adoption of scientific attitudes is shown in the following table.

Table 5. Description of student attitudes towards science on the indicator of scientific attitude

\begin{tabular}{|c|c|c|c|c|c|c|c|c|c|}
\hline \multicolumn{2}{|c|}{ Student Response } & Interval & $\mathbf{F}$ & $\%$ & Category & Mean & Med & Min & Max \\
\hline \multirow{10}{*}{$\begin{array}{c}\text { Middle } \\
\text { School } 34 \\
\text { Batanghari }\end{array}$} & \multirow{5}{*}{$\begin{array}{c}\text { VII } \\
\text { A }\end{array}$} & $8.0-14.4$ & 0 & 0 & Very Not Good & \multirow{5}{*}{3.7} & \multirow{5}{*}{4.0} & \multirow{5}{*}{2.0} & \multirow{5}{*}{5.0} \\
\hline & & $14.5-20.8$ & 1 & 2.9 & Not good & & & & \\
\hline & & $20.9-27.2$ & 13 & 37.1 & Enough & & & & \\
\hline & & $27.3-33.6$ & 16 & 45.7 & Good & & & & \\
\hline & & $33.7-40.0$ & 5 & 14.3 & Very good & & & & \\
\hline & \multirow{5}{*}{ VIIB } & $8.0-14.4$ & 0 & 0 & Very Not Good & \multirow{5}{*}{3.5} & \multirow{5}{*}{3.0} & \multirow{5}{*}{2.0} & \multirow{5}{*}{5.0} \\
\hline & & $14.5-20.8$ & 1 & 2.9 & Not good & & & & \\
\hline & & $20.9-27.2$ & 18 & 51.4 & Enough & & & & \\
\hline & & $27.3-33.6$ & 13 & 37.1 & Good & & & & \\
\hline & & $33.7-40.0$ & 3 & 8.6 & Very good & & & & \\
\hline \multirow{10}{*}{$\begin{array}{c}\text { Middle } \\
\text { School } 35 \\
\text { Batanghari }\end{array}$} & \multirow{5}{*}{ VIIA } & $8.0-14.4$ & 0 & 0 & Very Not Good & \multirow{5}{*}{3.3} & \multirow{5}{*}{3.0} & \multirow{5}{*}{2.0} & \multirow{5}{*}{5.0} \\
\hline & & $14.5-20.8$ & 2 & 5.8 & Not good & & & & \\
\hline & & $20.9-27.2$ & 21 & 60 & Enough & & & & \\
\hline & & $27.3-33.6$ & 11 & 31.3 & Good & & & & \\
\hline & & $33.7-40.0$ & 1 & 2.9 & Very good & & & & \\
\hline & \multirow{5}{*}{ VIIB } & $8.0-14.4$ & 0 & 0 & Very Not Good & \multirow{5}{*}{3.4} & \multirow{5}{*}{3.0} & \multirow{5}{*}{2.0} & \multirow{5}{*}{5.0} \\
\hline & & $14.5-20.8$ & 1 & 2.9 & Not good & & & & \\
\hline & & $20.9-27.2$ & 17 & 48.1 & Enough & & & & \\
\hline & & $27.3-33.6$ & 16 & 46.1 & Good & & & & \\
\hline & & $33.7-40.0$ & 1 & 2.9 & Very good & & & & \\
\hline
\end{tabular}

The description of students' attitudes towards science on the indicators of Fun in learning science is shown in the following table.
In the results of the descriptive statistical test of the attitude variable, there are two indicators. In the first indicator, namely the

Table 6. Description of student attitudes towards science on the indicators of fun in learning science

\begin{tabular}{|c|c|c|c|c|c|c|c|c|}
\hline Student Response & Interval & $\mathbf{F}$ & $\%$ & Category & Mean & Med & Min & Max \\
\hline \multirow{3}{*}{ VII } & $9.0-16.2$ & 0 & 0 & Very Not Good & \multirow[b]{3}{*}{3.4} & \multirow[b]{3}{*}{3.0} & \multirow[b]{3}{*}{2.0} & \multirow[b]{3}{*}{5.0} \\
\hline & $16.3-23.4$ & 1 & 2.9 & Not good & & & & \\
\hline & $23.5-30.6$ & 19 & 53.2 & Enough & & & & \\
\hline
\end{tabular}




\begin{tabular}{|c|c|c|c|c|c|c|c|c|c|}
\hline \multirow{7}{*}{$\begin{array}{c}\text { Middle } \\
\text { School } 34 \\
\text { Batanghari }\end{array}$} & & $30.7-37.8$ & 10 & 29 & Good & & & & \\
\hline & & $37.9-45.0$ & 5 & 14.9 & Very good & & & & \\
\hline & \multirow{5}{*}{$\begin{array}{c}\text { VII } \\
\text { B }\end{array}$} & $9.0-16.2$ & 0 & 0 & Very Not Good & \multirow{5}{*}{3.8} & \multirow{5}{*}{4.0} & \multirow{5}{*}{2.0} & \multirow{5}{*}{5.0} \\
\hline & & $16.3-23.4$ & 2 & 5.8 & Not good & & & & \\
\hline & & $23.5-30.6$ & 20 & 58 & Enough & & & & \\
\hline & & $30.7-37.8$ & 10 & 29 & Good & & & & \\
\hline & & $37.9-45.0$ & 3 & 8.2 & Very good & & & & \\
\hline \multirow{10}{*}{$\begin{array}{c}\text { Middle } \\
\text { School 35 } \\
\text { Batanghari }\end{array}$} & \multirow{5}{*}{$\begin{array}{c}\text { VII } \\
\text { A }\end{array}$} & $9.0-16.2$ & 0 & 0 & Very Not Good & \multirow{5}{*}{3.4} & \multirow{5}{*}{3.0} & \multirow{5}{*}{3.0} & \multirow{5}{*}{5.0} \\
\hline & & $16.3-23.4$ & 0 & 0 & Not good & & & & \\
\hline & & $23.5-30.6$ & 22 & 63.8 & Enough & & & & \\
\hline & & $30.7-37.8$ & 9 & 26.1 & Good & & & & \\
\hline & & $37.9-45.0$ & 4 & 11.1 & Very good & & & & \\
\hline & \multirow{5}{*}{$\begin{array}{c}\text { VII } \\
\text { B }\end{array}$} & $9.0-16.2$ & 0 & 0 & Very Not Good & \multirow{5}{*}{2.8} & \multirow{5}{*}{3.0} & \multirow{5}{*}{3.0} & \multirow{5}{*}{5.0} \\
\hline & & $16.3-23.4$ & 0 & 0 & Not good & & & & \\
\hline & & $23.5-30.6$ & 21 & 61.8 & Enough & & & & \\
\hline & & $30.7-37.8$ & 11 & 32.4 & Good & & & & \\
\hline & & $37.9-45.0$ & 2 & 5.9 & Very good & & & & \\
\hline
\end{tabular}

adoption of scientific attitudes contained in table 5 , it can be seen that the most dominant category in this indicator is Middle School 35 Batanghari class VII A and VII B in the sufficient category. So it can be concluded that Middle School 35 Batanghari has an advantage in students' attitudes towards indicators of scientific attitude adoption. Meanwhile, in the second indicator, namely pleasure in learning science, which is contained in table 6 , it can be seen that the most dominant category in this indicator is at Middle School 35 Batanghari in class VII A and VII B with a sufficient category. So it can be concluded that
Middle School 35 Batanghari has an advantage in students' attitudes towards the indicators of happy learning science.

This study is in line with research conducted by (Ningsi, 2020) which tested descriptive tests, but in this study only used one indicator, namely social implications, while in this study, descriptive results were tested on the attitude variable using two indicators.

The next variable in the descriptive statistical test is the science process skills of class VII A and VII B IPA students with classification indicators shown in the table below:

Table 7. Description of student science process skills on the indicator of classification

\begin{tabular}{|c|c|c|c|c|c|c|c|c|c|}
\hline \multicolumn{2}{|c|}{ Student Response } & Interval & $\mathbf{F}$ & $\%$ & Category & Mean & Med & Min & $\overline{\text { Max }}$ \\
\hline \multirow{8}{*}{$\begin{array}{c}\text { Middle } \\
\text { School } 34 \\
\text { Batanghari }\end{array}$} & & $5.0-5.75$ & 6 & 17.6 & Very Not Good & \multirow{4}{*}{2.3} & \multirow{4}{*}{3.0} & \multirow{4}{*}{1.0} & \multirow{4}{*}{4.0} \\
\hline & VII & $8.85-12.5$ & 9 & 24.4 & Not good & & & & \\
\hline & A & $12.6-16.25$ & 15 & 44.5 & Good & & & & \\
\hline & & $16.35-12.0$ & 5 & 14.5 & Very good & & & & \\
\hline & & $5.0-5.75$ & 9 & 24.4 & Very Not Good & \multirow{4}{*}{2.8} & \multirow{4}{*}{3.0} & \multirow{4}{*}{1.0} & \multirow{4}{*}{4.0} \\
\hline & VII & $8.85-12.5$ & 10 & 29 & Not good & & & & \\
\hline & \multirow[t]{2}{*}{ B } & $12.6-16.25$ & 10 & 29 & Good & & & & \\
\hline & & $16.35-12.0$ & 6 & 17.6 & Very good & & & & \\
\hline & & $5.0-5.75$ & 0 & 0 & Very Not Good & \multirow{3}{*}{2.4} & \multirow{3}{*}{3.0} & \multirow{3}{*}{2.0} & \multirow{3}{*}{4.0} \\
\hline & VII & $8.85-12.5$ & 7 & 20.3 & Not good & & & & \\
\hline Middle & A & $12.6-16.25$ & 11 & 31.4 & Good & & & & \\
\hline
\end{tabular}


School 35

\begin{tabular}{|c|c|c|c|c|c|c|c|c|}
\hline & $16.35-12.0$ & 17 & 49.3 & Very good & & & & \\
\hline & $5.0-5.75$ & 6 & 17.6 & Very Not Good & \multirow{4}{*}{2.4} & \multirow{4}{*}{2.0} & \multirow{4}{*}{1.0} & \multirow{4}{*}{3.0} \\
\hline VII & $8.85-12.5$ & 5 & 14 & Not good & & & & \\
\hline \multirow[t]{2}{*}{ B } & $12.6-16.25$ & 17 & 49.3 & Good & & & & \\
\hline & $16.35-12.0$ & 7 & 20.3 & Very good & & & & \\
\hline
\end{tabular}

The description of students' science process skills on science in the indicators of Arrange table is shown in the following table.
In the results of the descriptive statistical test of the science process skills variable, there are two indicators. In the first indicator, namely

Table 8. Description of students' science process skills on the indicator id Arrange table

\begin{tabular}{|c|c|c|c|c|c|c|c|c|c|}
\hline \multicolumn{2}{|c|}{ Student Response } & Interval & $\mathbf{F}$ & $\%$ & Category & Mean & Med & Min & Max \\
\hline \multirow{8}{*}{$\begin{array}{c}\text { Middle } \\
\text { School } 34 \\
\text { Batanghari }\end{array}$} & \multirow{4}{*}{$\begin{array}{c}\text { VII } \\
\text { A }\end{array}$} & $3.0-5.25$ & 4 & 11.4 & Very Not Good & \multirow{4}{*}{2.3} & \multirow{4}{*}{3.0} & \multirow{4}{*}{1.0} & \multirow{4}{*}{4.0} \\
\hline & & $5.35-7.5$ & 16 & 45.7 & Not good & & & & \\
\hline & & $7.6-9.75$ & 15 & 42.9 & Good & & & & \\
\hline & & $9.85-12.1$ & 0 & 0 & Very good & & & & \\
\hline & \multirow{4}{*}{$\begin{array}{c}\text { VII } \\
\text { B }\end{array}$} & $3.0-5.25$ & 8 & 23.5 & Very Not Good & \multirow{4}{*}{2.8} & \multirow{4}{*}{3.0} & \multirow{4}{*}{1.0} & \multirow{4}{*}{4.0} \\
\hline & & $5.35-7.5$ & 15 & 44.1 & Not good & & & & \\
\hline & & $7.6-9.75$ & 4 & 11.8 & Good & & & & \\
\hline & & $9.85-12.1$ & 7 & 20 & Very good & & & & \\
\hline \multirow{8}{*}{$\begin{array}{c}\text { Middle } \\
\text { School } 35 \\
\text { Batanghari }\end{array}$} & \multirow{4}{*}{$\begin{array}{c}\text { VII } \\
\text { A }\end{array}$} & $3.0-5.25$ & 7 & 20 & Very Not Good & \multirow{4}{*}{2.4} & \multirow{4}{*}{3.0} & \multirow{4}{*}{2.0} & \multirow{4}{*}{4.0} \\
\hline & & $5.35-7.5$ & 14 & 40 & Not good & & & & \\
\hline & & $7.6-9.75$ & 13 & 37.1 & Good & & & & \\
\hline & & $9.85-12.1$ & 1 & 2.9 & Very good & & & & \\
\hline & \multirow{4}{*}{$\begin{array}{c}\text { VII } \\
\text { B }\end{array}$} & $3.0-5.25$ & 2 & 5.9 & Very Not Good & \multirow{4}{*}{2.4} & \multirow{4}{*}{2.0} & \multirow{4}{*}{1.0} & \multirow{4}{*}{3.0} \\
\hline & & $5.35-7.5$ & 6 & 17.6 & Not good & & & & \\
\hline & & $7.6-9.75$ & 21 & 61.8 & Good & & & & \\
\hline & & $9.85-12.1$ & 5 & 14.7 & Very good & & & & \\
\hline
\end{tabular}

the classification based on table 7, it can be seen that the most dominant category in the above indicators is in Middle School 35 Batanghari class VII A and VII B in the good category. So it can be concluded that Middle School 35 Batanghari has advantages in students' science process skills on classification indicators. In the second indicator, which is compiling a table based on the results of table 8 , it can be seen that the most dominant category in the above indicators is in Middle School 35 Batanghari class VII A and VII B in the good category. So it can be concluded that SMP 35 Batanghari has advantages in students' science process skills in the indicators of compiling tables. This study is in line with research conducted by (Van et al., 2020) which tested the descriptive test, but in this study only tested the mean while in this study tested the mean,

Table 9. Normality test of attitude and science process skills class VII A and VII B

\begin{tabular}{cccccccc}
\hline \multirow{2}{*}{ Variable } & \multirow{2}{*}{ Class } & \multicolumn{3}{c}{ Kolmogorov-Smirnov } & \multicolumn{3}{c}{ Shapiro-Wilk } \\
\cline { 2 - 7 } & & Statistic & Df & Sig. & Statistic & Df & Sig. \\
\hline \multirow{2}{*}{ Attitude } & VII_A & .096 & 70 & $.200^{*}$ & .973 & 70 & .396 \\
& VII_B & .123 & 70 & .137 & .956 & 70 & .185 \\
\hline \multirow{2}{*}{ Science } & VII_A & .0994 & 70 & .200 & .975 & 70 & .725 \\
process skills & VII_B & .095 & 70 & $.200^{*}$ & .964 & 70 & .362 \\
\hline
\end{tabular}


median, max, min, interval, frequence, and category.

\section{Comparative Analysis}

The normality test of students' attitude and science process skills in grades VII A and VII $\mathrm{B}$ is described in Table 10. The linearity test of students' attitude and science process skills in class VII A and VII B is described in Table 11. The T-test of student attitude in grades VII A and VII B is described in Table 12. The correlation test of students' Attitide and science process skills in class VII A and VII B is described in Table 13.

Table 10. Linearity test of attitude and science process skills of class VII A and VII B students

\begin{tabular}{ccc}
\hline Variable & Class & Signifikan \\
\hline Attitude * science process skills & VII A & .044 \\
\cline { 2 - 3 } & VII B & .025 \\
\hline
\end{tabular}

Table 11. T-test of student Attitide and science process skills of grade VII A and VII B students

\begin{tabular}{lccc}
\hline Class & Variable & N & Sig. (2-tailed) \\
\hline \multirow{2}{*}{ VII A } & Attitide & 70 & 0.048 \\
\cline { 2 - 4 } & Science process skills & 70 & 0.047 \\
\hline \multirow{2}{*}{ VII B } & Attitide & 70 & 0.039 \\
\cline { 2 - 4 } & Science process skills & 70 & 0.038 \\
\hline
\end{tabular}

Table 12. Correlation test of attitude and science process skills for grades VII A and VII B

\begin{tabular}{lcccc}
\hline Class & Variable & N & Pearson Correlation & Sig. (2-tailed) \\
\hline VII A & Attitide & 70 & 0,762 & 0,035 \\
VII B & science process skills & 70 & 0,754 & 0,037 \\
\hline
\end{tabular}

The first comparative test is the normality test. The data is normally distributed as seen from the significance value, if the significance value is $>0.05$ then the data is normal. While the significance value $<0.05$, the data is not normal. Based on the results of table 9, the normality test was obtained using the Kolmogorov-Smoniv test, a significance value $>0.05$, it can be concluded that the data is normally distributed. The next test is about linearity. Linearity testing is done to see the linear relationship between two or more variables. Conditions in this test, if the significance value $<0.05$. Based on table 10 , it can be seen that the linearity test results obtained that the significance value has met the requirements $<0.05$. It can be concluded that there is a linear relationship between attitudes and science process skills for students of class VII A and VII B.

The next test is the $\mathrm{T}$ test. This test is conducted to determine the differences between variables in science subjects. The condition in this test is that if the significance value is $>0.05$, it can be said that the variable has no difference. If the significance value $<0.05$, then the variable has a significant difference. From table 11, it is known that there are differences in the attitudes and skills of the students of class VIIA and VII B science towards science subjects. This is evidenced by the value of sig (2-tailed) $<0.05$. In this test, it was conducted to determine the relationship of variables to science subjects. The condition in this test is that if the significance value 
is $>0.05$, it can be said that the variable has no relationship. If the significance value $<0.05$, then the variable has a significant relationship. The results obtained are shown in the following table. From table 12 it is known that there is a relationship between attitudes and science process skills for grades VII A and VII B with science subjects. This is evidenced by the value of sig $(2$-tailed $)<0.05$.

This research is in line with previous research conducted by (Sultan \& Bancong, 2017) about students' attitudes towards science. However, previous studies only tested for homogeneity and normality and also the study did not test classes and two schools as this study did. In this study, there was a homogeneity test that was not carried out by the study where this homogeneity test aimed to determine whether this study had homogeneous variations. Normality research aims to determine whether the average attitude of students comes from a distributed population. So that previous research did not examine some of the tests carried out by this study in more detail and detail to get accurate and complete results about students' attitudes towards science in junior high school.

This research is in line with previous research conducted by (Utami \& Wutsqa, 2017) on students' science process skills. However, previous studies only tested science process skills without comparing them with attitudes as in this study. The study also did not conduct a correlation test where the correlation test conducted in this study was to determine the ability to solve problems closely with students' beliefs about the problem, because students' confidence in solving problems will affect student learning outcomes. So that previous research did not examine some of the tests carried out by this study in detail and in full on science process skills towards science in junior high schools.
The novelty of this study examines the learning model in the form of problem based learning and problem solving and science process skills for grade VII A and VII B students at Middle School 34 Batanghari and Middle School 35 Batanghari which has not been done by other research. By doing several tests, namely descriptive statistical tests which consist of 4 indicators, namely 2 attitude indicators and 2 science process skills indicators. The next test is about the analysis prerequisite test or assumption test. 2 tests carried out are normality test, and linearity test, as well as $\mathrm{T}$ test and correlation test. The test was conducted to find out if there was a difference between Middle School 34 Batanghari and Middle School 35 Batanghari, and to see if there was a difference in skills between the two schools. Tests were also conducted to determine whether the data were normal and linear in each class. And is there a significant comparison between the two schools.

The limitation of this study is that it only measures attitudes and science process skills in students, but testing with other variables such as interest has not been carried out, motivation and others. Interest in learning is a very important factor in the success of students so that students can be involved in the activities they experience so that they are not bored or bored. Moreover, motivation makes students will continue to be eager to continue learning without coercion from any party. So that interest and motivation are very important to be tested in further research. The researcher suggests to conduct further research to compare the interest variable or process skills with other variables such as motivation or learning model and the researcher suggests to conduct research at the junior secondary or senior high school level. 


\section{CONCLUSIONS}

Based on the results of hypothesis testing, research testing and data analysis, the conclusions of this study were 70 attitudes from 2 classes, namely class VII A \& VII B, each 20 women and 15 men. Then the sample of science process skills was 70 from 2 classes, namely VII A \& B with 20 female students and 15 male students respectively. This research was conducted between Middle School 34 Batanghari and Middle School 35 Batanghari. The results of the study using the $\mathrm{T}$ test that there were significant differences in the indicators of attitudes and science process skills of students in two schools and two classes, namely VII A and VII B. The results of the correlation test between attitudes and science process skills of students in grades VII A and VII B showed that attitudes and science process skills are related.

\section{REFERENCES}

Alsabahi, M. A., Maisurah, K., Bahador, K., \& Saat, R. M. (2021). Cogent Business \& Management The influence of personal characteristics and workplace learning on information technology competencyamong external auditors/ : The role of organisational culture as a moderator The influence of personal characteristics and wo. Cogent Business \& Management, $8(1)$.

Anggiato, \& Setiawan. (2019). Metodologi penelitian kualitatif [Qualitative research methodology]. Jawa Barat: CV Jejak.

Anggraeni, H., Fauziyah, Y., \& Fahyuni, E. F. (2019). Penguatan Blended Learning Berbasis Literasi Digital Dalam Menghadapi Era Revolusi Industri 4.0 [Strengthening Blended Learning Based on Digital Literacy in Facing the Era of the Industrial Revolution 4.0]. Al-Idarah/: Jurnal Kependidikan Islam, 9(2), 190-
203.

Anif, S., Sutopo, A., \& Prayitno, H. J. (2020). Lesson study validation: Model for social and natural sciences teacher development in the implementation of national curriculum in Muhammadiyah schools, Indonesia. Universal Journal of Educational Research, 8(1), 253259.

Anisah, A. S., \& Suntara, H. (2020). Penerapan Metode Pembelajaran Debate Untuk Meningkatkan Kecerdasan Emosional Siswa [Application of the Debate Learning Method to Improve Students' Emotional Intelligence]. Jurnal Pendidikan Universitas Garut, 14(1), 138-147.

Astalini, A., Kurniawan, D. A., \& Sumaryanti, S. (2018). Sikap Siswa Terhadap Pelajaran Fisika di SMAN Kabupaten Batanghari [Students'Attitudes towards Physics Lessons at SMAN Batanghari Regency]. Jurnal Ilmu Pendidikan Fisika, 3(2), 59.

Bankole, Q.A., \& Nasir, Z. (2020). Empirical Analysis of Undergraduate Students ' Perception in the Use of Electronic Sources in Kwara State University Library. International Information \& Library Review, 0(0), 1-11.

Century, J., Ferris, K. A., \& Zuo, H. (2020). Finding time for computer science in the elementary school day: a quasiexperimental study of a transdisciplinary problem-based learning approach. International Journal of STEM Education, 7(1).

Cooper, G., \& Berry, A. (2020). Demographic predictors of senior secondary participation in biology, physics, chemistry and earth/ space sciences: students' access to cultural, social and science capital. International Journal of Science Education, 42(1), 
151-166.

Crawley, E. F., Hosoi, A., Long, G. L., Kassis, T., Dickson, W., \& Mitra, A. B. (2019). Moving Forward with the New Engineering Education Transformation (NEET) program at MIT - Building community, developing projects, and connecting with industry. In ASEE Annual Conference and Exposition, Conference Proceedings.

Creswell, J. W. (2012). Educational Research. Lincoln: University of Nebraska.

Darmaji, D., Kurniawan, D. A., \& Irdianti, I. (2019). Physics education students' science process skills. International Journal of Evaluation and Research in

Effendy, L., \& Leilani, A. (2021). Adoption of Integrated Rice Crop Management in. International Journal of Innovative Science and Research Technology, 6(4).

Emilzoli, M., Ali, M., \& Rusman. (2021). Perceptions, attitudes and lifestyles of students of Madrasah Ibtidaiyah Teacher Education Study Program about education for sustainable development. IOP Conference Series: Earth and Environmental Science, 739(1).

Erdogan, S. C. (2017). Science Teaching Attitudes and Scientific Attitudes of PreService Teachers of Gifted Students. Journal of Education and Practice, $8(6), 164-170$.

Flores-Tena, M. J. (2020). The Educational Inclusion in the Deficit of Attention of Elementary Students. International Journal of Educational Research Review, 265-273.

Fromowitz. (2017). Batch and history sampling for fixed-source monte carlo problems. Nuclear Science and Engineering, 187(2), 142-153.

Halim, L., Abd Rahman, N., Zamri, R., \& Mohtar, L. (2018). The roles of parents in cultivating children's interest towards science learning and careers. Kasetsart Journal of Social Sciences, 39(2), 190196.

Harefa, A. R. (2019). Peran Ilmu Fisika Dalam Kehidupan Sehari-Hari [The Role of Physics in Daily Life]. Warta Edisi 60, April, 91-96.

Hennink. (2020). Qualitative research methods. India: Sege.

Hidayat, Z., Ratnawulan, \& Gusnedi. (2019). Analysis of learning media in developing science textbooks with theme energy in life using integrated model for integrated $21 \mathrm{st}$ century learning. Journal of Physics: Conference Series, 1185(1).

Hong, L. Y., \& Talib, C. A. (2018). Scientific Argumentation in Chemistry Education: Implications and Suggestions. Asian Social Science, 14(11), 16.

Hutauruk, P., \& Simbolon, R. (2018). Meningkatkan Hasil Belajar Siswa Dengan Alat Peraga Pada Mata Pelajaran Ipa Kelas Iv Sdn Nomor 14 Simbolon Purba [Improving Student Learning Outcomes With Teaching Aids on Science Subjects Class IV Sdn Number 14 Simbolon Purba]. School Education Journal, 8(2), 112.

Imaduddin, M., \& Khafidin, Z. (2018). Ayo Belajar IPA dari Ulama: Pembelajaran Berbasis Socio-Scientific Issues di Abad $k e-21$ [Socio-Scientific Issues-Based Learning in the 21st Century]. Thabiea/: Journal of Natural Science Teaching, 1(2), 102.

Karaçam, S., Dani ${ }^{\circ}$ man, a ., Bilir, V., \& Digilli Baran, A. (2020). A Scale Development Study: Scientist Image, Gender of the Scientist and Risks of being Scientist. International Journal of Psychology and Educational Studies, 7(3), 235-256.

Kjeldsen, K. (2019). A study-of-religion(S)- 
based religion education: Skills, knowledge, and aims. Center for Educational Policy Studies Journal, 9(4), 11-29.

Kruit, P. M., Oostdam, R. J., van den Berg, E., \& Schuitema, J. A. (2018). Assessing students' ability in performing scientific inquiry: instruments for measuring science skills in primary education. Research in Science and Technological Education, 36(4), 413-439.

Kurniawan, D. A., Astalini, A., \& Anggraini, L. (2018). Evaluasi sikap siswa SMP terhadap IPA di Kabupaten Muaro Jambi [Evaluation of junior high school students' attitudes towards science in Muaro Jambi Regency]. Jurnal Ilmiah Didaktika, 19(1), 124-139.

Labouta, H. I., Kenny, N. A., Li, R., Anikovskiy, M., Reid, L., \& Cramb, D. T. (2018). Learning science by doing science: an authentic science process-learning model in postsecondary education. International Journal of Science Education, 40(12), 1476-1492.

Llussà, A. S., Guilar, D., \& Ibáñez, M. (2019). Video worked examples to promote elementary students' science process skills: a fruit decomposition inquiry activity. Journal of Biological Education, $00(00), 1-12$.

Madu, B. C. (2020). Scientific Explanation of Phenomenon, Imagination and Concept Formation as Correlates of Students' Understanding of Physics Concepts. Journal of Natural Sciences Research, 11(16), 17-28.

Maharaj-Sharma, R., \& Sharma, A. (2017). Using ICT in Secondary School Science Teaching - What Students and Teachers in Trinidad and Tobago Say? European Journal of Education Studies, 3(2), 197 -
211.

Maison, M., Lestari, N., \& Widaningtyas, A. (2019). Identifikasi Miskonsepsi Siswa Pada Materi Usaha Dan Energi [Identification of Students' Misconceptions on Work and Energy Materials]. Jurnal Penelitian Pendidikan IPA, 6(1), 32.

Manzilati. (2017). Metodologi penelitian kualitativel : paradigma, metode dan aplikasi [Qualitative research methodologies: paradigms, methods and applications]. Malang: UB press.

Marshel, J., \& Ratnawulan. (2020). Analysis of Students Worksheet (LKPD) integrated science with the theme of the motion in life using integrated connected type 21 st century learning. Journal of Physics: Conference Series, 1481(1).

Muslih, M. (2020). Sains, dari Pengetahuan Khusus, Aktivitas Ilmiah, hingga Disiplin Ilmu [Science, from Specific Knowledge, Scientific Activities, to Disciplines]. In Falsafah Sains (Issue July 2019).

Mutiani. (2021). Pembinaan Etika Peserta Didik Melalui Pembelajaran Tematik Integratif di Sekolah Dasar [Ethical Development of Students Through Thematic - Integrative Learning in Elementary Schools]. Edukatif: Jurnal Ilmu Pendidikan, 3(3).

Mutlu,A. (2020). Evaluation of students' scientific process skills through reflective worksheets in the inquiry-based learning environments. Reflective Practice, 21(2), 271-286.

Ningsi, A. P. (2020). Deskripsi Sikap Siswa Terhadap Pembelajarn IPA di SMPN 1 Muaro Jambi [Description of Students' Attitudes towards Science Learning at SMPN 1 Muaro Jambi]. Ibriez/: Jurnal Kependidikan Dasar Islam Berbasis 
272 | Jurnal Pendidikan Progresif, Vol. 11, No. 2, pp. 258-274, August 2021

Sains.

Nurmayani, L., Doyan, A., \& Sedijani, P. (2018). Pengaruh Model Pembelajaran Inkuiri Terbimbing Terhadap Hasil Belajar Fisika Peserta Didik [The Influence of Guided Inquiry Learning Models on Students' Physics Learning Outcomes]. Jurnal Penelitian Pendidikan IPA, 4(2), $2-7$.

Puspitasari, T. O., Putri, Y. E., \& Yohanes, Y. (2019). Sikap Terhadap Konsentrasi Belajar Siswa Pada Mata Pelajaran Fisika di Sekolah Menengah Atas [Attitudes Against Student Learning Concentration in Physics Subjects in High School]. Jurnal Inovasi Pendidikan Fisika Dan Riset Ilmiah, 3(2), 79-85.

Putra, A., Masril, M., \& Yurnetti, Y. (2018). Planning Model of Physics Learning in Senior High School to Develop Problem Solving Creativity Based on National Standard of Education. IOP Conference Series: Materials Science and Engineering, 335(1).

Raharjo, Y. K., . S., \& . W. (2019). Need Analysis of Learning Model of History Integrated with Leadership Values of Mangkunegara I through Reflective Pedagogy Paradigm. International Journal of Educational Research Review, 4(4), 617-623.

Ramdani, A., Jufri, A. W., Gunawan, G., Hadisaputra, S., \& Zulkifli, L. (2019). Pengembangan Alat Evaluasi Pembelajaran Ipa Yang Mendukung Keterampilan Abad 21 [Development of Science Learning Evaluation Tools that Support 21st Century Skills]. Jurnal Penelitian Pendidikan IPA, 5(1).

Rosdianto, H. (2017). Pengaruh Model Generative Learning Terhadap Hasil Belajar Ranah Kognitif Siswa Pada Materi Hukum Newton [Learning Against
Student Cognitive Learning Outcomes on Newton's Law Material]. Jurnal Pendidikan Fisika Dan Keilmuan (JPFK), 3(2), 66.

Rosdianto, H. (2018). Rancang Bangun Alat Praktikum Gerak Jatuh Bebas [Design and Build of Free Fall Motion Practicum Tool]. Jurnal Ilmu Pendidikan Fisika, $3(1), 20-23$.

Rukin. (2019). Penelitian kualitatif. Sulawesi:Ahmar cendikia Indonesia.

Setiawan, A. (2017). Hubungan Self Confidence Dan Anxiety Dengan Prokrastinasi Akademik Pada Siswa Kelas X Ma Darut Taqwa Purwosari Pasuruan [The Relationship of Confidence and Anxiety with Academic Procrastination in Class X Students of Ma Darut Taqwa Purwosari Pasuruan]. Jurnal Psikologi, 4(2), 71-84.

Setiawan, Innatesari, D. K., Sabtiawan, W. B., $\&$ Sudarmin, S. (2017). The development of local wisdom-based natural science module to improve science literation of students. Jurnal Pendidikan IPA Indonesia, 6(1), 49-54.

Solé-Llussà, A., Aguilar, D., \& Ibáñez, M. (2020). Video-worked examples to support the development of elementary students' science process skills: a case study in an inquiry activity on electrical circuits. Research in Science and Technological Education, 00(00), 1-21. Sriyanti, I. (2021). Sikap Siswa Dalam Belajar Matematika Melalui Model Pembelajaran Learning Cycle 5E [Students' Attitudes in Learning Mathematics Through the 5E Learning Cycle Model]. Pasundan Journal of Mathematics Education (PJME), 11(1), 36-49.

Stender, A., Schwichow, M., Zimmerman, C., \& Härtig, H. (2018). Making inquiry- 
based science learning visible: the influence of CVS and cognitive skills on content knowledge learning in guided inquiry. International Journal of Science Education, 40(15), 1812-1831. Stylinski, C. D., Peterman, K., Phillips, T., Linhart, J., \& Becker-Klein, R. (2020). Assessing science inquiry skills of citizen science volunteers: a snapshot of the field. International Journal of Science Education, Part B: Communication and Public Engagement, 10(1), 77-92.

Sudibyo, E., Nurita, T., \& Fauziah, A. N. M. (2018). Keterampilan Proses Untuk Melatihkan Keterampilan Proses [Process Skills To Practice Process Skills]. Jurnal Penelitian Pendidikan IPA, 3(1), 21-26.

Sultan, A. D., \& Bancong, H. (2017). Pengaruh Pendekatan Multiple Intelligences Melalui Model Pembelajaran Langsung Terhadap Sikap Dan Hasil Belajar Fisika Peserta Didik Kelas XI IPA SMA Negeri 11 Makassar [The Effect of Multiple Intelligences Approach Through Direct Learning Model on Attitudes and Learning Outcomes of Physics Students of Class XI IPA SMA Negeri 11 Makassar]. Jurnal Pendidikan Fisika Unismuh, 5(1), 120620.

Suwendra. (2018). Metodologi penelitian kualitatif. Bandung: Nigacakra.

Tao, H., \& Ning, J. (2018). Computation Randomized quasi-random sampling / importance resampling. Communications in Statistics - Simulation and Computation, O(0), 1-13.

Tolley. (2014). Qualitative Methods in Public health/: a Field Guide For Applied Research. Willey.

Utami, R. W., \& Wutsqa, D. U. (2017). Analisis kemampuan pemecahan masalah matematika dan self-efficacy siswa SMP negeri di Kabupaten Ciamis [Analysis of mathematical problem solving abilities and self-efficacy of public junior high school students in Ciamis District]. Jurnal Riset Pendidikan Matematika, 4(2), 166.

Van der Aalsvoort, G., van der Zee, S., \& de Wit, T. (2020). Improving science skills by practicing geometry and measurement in Kindergarten. Early Child Development and Care, 190(4), 537-548.

Vansteensel, M. J., Kristo, G., Aarnoutse, E. J., \& Ramsey, N. F. (2017). The braincomputer interface researcher's questionnaire: from research to application. Brain-Computer Interfaces, 4(4), 236247.

Vartiainen, J., \& Kumpulainen, K. (2020). Playing with science: manifestation of scientific play in early science inquiry. European Early Childhood Education Research Journal, 28(4), 490-503.

Vosniadou, S. (2019). The Development of Students' Understanding of Science. Frontiers in Education, 4(April), 1-6.

Wahyudi, E. E., Aminah, N. S., \& Sukarmin. (2017). Pembelajaran Optika Geometri Melalui Problem Based Learning (PBL) Ditinjau Dari Kemampuan Berpikir Kritis Siswa Dan Kemampuan Berpikir Kreatif Siswa SMA Kelas X Tahun 2014/ 2015 [Geometric Optical Learning through Problem Based Learning (PBL) in terms of students' critical thinking skills and creative thinking skills of high school students in class X 2014/2015]. Jurnal Inkuiri, 6(3), 49-60.

Warfa, A. R. M., Nyachwaya, J., \& Roehrig, G. (2018). The influences of group dialog on individual student understanding of science concepts. International Journal of STEM Education, 5(1).

Wulandari, A., Handayani, P., \& Prasetyo, D. R. 
274 | Jurnal Pendidikan Progresif, Vol. 11, No. 2, pp. 258-274, August 2021

(2019). Pembelajaran Ilmu Pengetahuan Alam Berbasis EMC (Education Mini Club) sebagai Solusi Menghadapi Tantangan Pendidikan dI Era Revolusi Industri 4.0 [EMC (Education Mini Club)-Based Natural Science Learning as a Solution to the Challenges of Education in the Era of the Industrial Revolution 4.0]. Thabiea/ : Journal of Natural Science Teaching, 2(1), 51.

Zariæ, J., Hasselhorn, M., \& Nagler, T. (2021). Orthographic knowledge predicts reading and spelling skills over and above general intelligence and phonological awareness.

European Journal of Psychology of

Education, 36(1), 21-43. 